\title{
Voter Turnout Decline and Party Responsiveness
}

\author{
Lawrence Ezrow ${ }^{1}$ and Werner Krause ${ }^{2 *}$ (D) \\ ${ }^{1}$ University of Essex, Essex, UK and ${ }^{2}$ Humboldt-Universität zu Berlin, Berlin, Germany \\ ${ }^{\star}$ Corresponding author. Email: werner.krause@hu-berlin.de
}

(Received 27 October 2020; revised 10 June 2021; accepted 16 November 2021; first published online 7 February 2022)

\begin{abstract}
Numerous studies conclude that declining turnout is harmful for democracy. However, we uncover the arguably positive effect that political parties become more responsive to the median voter in the election after turnout has decreased. We assume that parties are vote seeking and show that moderate voters are responsible for changes in turnout, and we argue that declining turnout in an election sends a clear signal to political parties that there is an opportunity to mobilize disaffected voters in the following election by responding to changes in public opinion. We report the results of statistical analyses on data from thirteen democracies from 1977 to 2018 that provide evidence that declining voter turnout in one inter-election period is associated with increasing party responsiveness to public opinion in the following period. Our findings have important implications for our understanding of voter turnout, political representation, and parties' election strategies.
\end{abstract}

Keywords: elections; political representation; voter turnout; party policy positions; party responsiveness

Several studies identify party responsiveness to shifts in public opinion as a key component in the representative process and use this framework extensively to analyze policy linkages between citizens and parties over time (Dassonneville 2018; Ferland 2020; Homola 2019; Klüver and Spoon 2016; Spoon and Klüver 2014; Spoon and Klüver 2015; Williams and Spoon 2015). Prominent research in the discipline also recognizes the importance of electoral participation for democracy (for example, Blais 2000; Franklin 2004; Lijphart 1997; see also Norris 2002). Discussing the importance of voting, Russell Dalton $(2006,42)$ states that "voting is the one activity that binds the individual to the political system and legitimizes the rest of the democratic process." Democratic ideals suggest that policy preferences of citizens will translate into the selection of representatives, who, in turn, produce policies (Powell 2000). These ideals assume that a participatory electorate is crucial for the functioning of democracy.

We examine the relationship between turnout and responsiveness by addressing the question: how do changes in turnout influence party responsiveness to the median voter? The empirical analyses of political parties in thirteen democracies from 1977 to 2018 support the finding that when voter turnout declines in an election, mainstream political parties are more responsive to shifts in the median voter position in the following election to appeal to disaffected voters. Thus, parties are sensitive to changes in turnout; however, it is the decreases in turnout that then motivates political elites to respond to shifts in public opinion in the following election. Indeed, there are recent cases which suggest that this occurs. In Germany, after a low turnout election in 2009, the Social Democratic Party (SPD) nominated centrist candidate Peer Steinbrück in 2013 as its leader in an attempt to appeal to moderate disaffected citizens in the 
"waiting room"1 that the party believed were ready to be mobilized. ${ }^{2}$ Mobilizing disaffected voters was a strategy also carried out in the 2010 UK election by the Conservatives (led by centrist leader David Cameron) when they managed to secure the largest share of citizens that had abstained in the previous election. ${ }^{3}$

There are several reasons why our findings are important. First, they relate to the dynamic representation model of elections developed by Stimson, MacKuen, and Erikson (1995; Erikson, MacKuen, and Stimson 2002). This model identifies party responsiveness to shifts in public opinion as a key component in the representative process (see also the "thermostatic model" developed by Wlezien $(1995 ; 1996)$ ), and several comparative scholars have also focused on this linkage between citizens and parties over time (for example, Adams et al. 2004; Soroka and Wlezien 2010). ${ }^{4}$

Secondly, the study relates to the empirical and theoretical studies of parties' election strategies (for example, Dow 2001; Dow 2011; Downs 1957; Somer-Topcu 2015; Spoon 2011), and, more specifically, scholars have identified "decision rules" for parties that seek office facing uncertainty in elections and difficulty in calculating optimal strategies (for example, Budge 1994; Laver 2005). These studies develop on arguments that parties rely on heuristics or "shortcuts" to deal with circumstances of complexity and uncertainty. Virtually all of these studies consider the possibility that parties' past election results or rival parties' positions inform the decision rules that parties use to adopt policy in the current election (Adams and Somer-Topcu 2009a; Budge 1994; Budge, Ezrow, and McDonald 2010; Laver 2005; Somer-Topcu 2009; see also Lindvall, Rueda, and Zhai 2021). This study is the first to connect current party policy strategies to previous turnout, that is, that parties also incorporate information about changing voter turnout in formulating their future electoral strategies.

Thirdly, the study raises implications for our understanding of the effects of turnout. Cross-national empirical studies of voter turnout have shown that high levels of turnout are associated with high levels of citizen satisfaction with democracy (for example, Anderson and Guillory 1997; Franklin 2004; Hobolt 2012). ${ }^{5}$ Here, it is shown that turnout changes have clear effects for parties' policy positions and their sensitivity to shifts in public opinion.

Fourthly, and related, the study identifies an additional normative standard for measuring the health of democracy. As noted, scholars widely view voter turnout as a bellwether for assessing the health of democracy. The implication of virtually all studies of political participation and turnout is that elites will be more responsive to voters when they anticipate high levels of turnout. Yet, the finding that is reported here is that turnout decline and party responsiveness are related. In this light, the importance of the study is to generate a focus on whether decreasing turnout is

\footnotetext{
${ }^{1}$ Translation by authors, quoted from Süddeutsche Zeitung (available at: https://www.sueddeutsche.de/1.1757398).

${ }^{2}$ Prior to the nomination, in the 2009 elections, German voter turnout decreased dramatically (to 70.8 per cent), with the SPD suffering a catastrophic 11 percentage point decrease in its vote share from 2005. During the election campaign, the SPD leadership repeatedly underlined the need to mobilize citizens that had abstained in the 2009 elections. In fact, the SPD leadership openly speculated that if turnout increased by 5-7 percentage points, the party could gain the most votes in the upcoming election. Steinbrück claimed that the party's past vote loss was not due to voters switching, but instead that former SPD voters could be mobilized. In the aftermath of the 2009 turnout decline, we can interpret the 2013 SPD's leadership selection and their public comments as a clear attempt to gain votes by appealing to centrist citizens that had abstained in the previous election. See, e.g., reports in the newspapers Welt (available at: https://www.welt.de/article120085169) or Focus (available at: https://www.focus.de/_aid_1029828.html).

${ }^{3}$ See, e.g., James Kirkup, "None of the above. The role of non-voters in the General Election 2015" (available at: https://www. britishelectionstudy.com/bes-findings/none-of-the-above-the-role-of-non-voters-in-general-election-2015-by-james-kirkup).

${ }^{4}$ The studies that analyze mean voter representation and dynamic representation are similar, in that they are each concerned with how elites represent citizens. However, mean voter representation and dynamic representation differ, in that the former concept focuses on the party-citizen linkage in elections, while the latter refers to responsiveness of government policy outputs.

${ }^{5}$ Ezrow and Xezonakis (2016) argue that if the relationship between citizen satisfaction and voter turnout is analyzed within countries and over time, decreases in citizen satisfaction with democracy will lead to increases in voter turnout.
} 
met with a subsequent increase in party responsiveness. Put differently, if parties remain unresponsive to the median voter position after turnout decreases, this could signal that policy linkages between parties and citizens are deteriorating. Turnout should be seen not only as an expression of satisfaction with democracy and institutions, but also as a mechanism to signal an absence of responsiveness to the median. Declines in turnout often have a "silver lining," in that they prompt parties to be more attentive to future shifts in public opinion.

\section{Declining Turnout and Increasing Party Responsiveness}

We assume that parties are vote seeking and that the largest changes in turnout patterns occur among moderate voters (Rodon 2017). Declining turnout in a focal election sends a clear signal to political parties to respond to the median voter in an effort to mobilize disaffected voters for the next election. This expectation is based on numerous studies which report that when parties appeal to citizens in terms of policy, they will be more likely to turnout to vote (see, for example, Adams, Dow, and Merrill 2006; Dreyer and Bauer 2019; Hobolt and Hoerner 2020; Lefkofridi, Giger, and Gallego 2014; Plane and Gershtenson 2004; Reher 2014).

Persuasive arguments suggest that shifts in the median voter position will influence parties' policy shifts because they seek to maximize votes. Prominent researchers of mainstream parties have observed that these parties have expanded their range of ideological appeals and that they have shed their "ideological baggage" (Kirchheimer 1966; see also Kitschelt 1997; Van Kersbergen 1999). The result is that mainstream parties are sensitive to shifts in public opinion (see, for example, Adams et al. 2004). Maximizing votes may not be an end goal in itself; rather, vote maximization is an efficient strategy for office- and policy-seeking parties (see Müller and Strøm 1999). For an office-seeking party in a multiparty system, increased vote shares enhance its position for postelection coalition negotiations. In the latter case, for a policy-seeking party, its leverage to pull the governing coalition's policy in its preferred direction will increase as its electoral strength increases as well. ${ }^{6}$ Thus, there are theoretical arguments to suggest that parties-whether they are vote, office, or policy seeking-will be responsive to changes in the median voter position in the general electorate (see, for example, Adams and Merrill 2009; Downs 1957; Huber and Powell 1994; McDonald and Budge 2005; Stimson, MacKuen, and Erikson 1995). ${ }^{7}$

If turnout decisions are based on how close citizens are to the most proximate party in policy terms (Adams, Dow, and Merrill 2006; Dreyer and Bauer 2019; Hobolt and Hoerner 2020; Lefkofridi, Giger, and Gallego 2014; Plane and Gershtenson 2004; Reher 2014), political parties will be more sensitive to the left-right preference of the median voter after voter turnout decreases. Previous turnout decline signals that there are more moderate disaffected voters that may potentially vote in the following election. One reason why parties appeal to moderates in these circumstances is because there are typically more voters in the middle than there are at the extremes (see Adams and Somer-Topcu 2009b). Furthermore, the variation in individual turnout is lower at the extremes. Distinctly noncentrist voters also tend to hold a higher intensity of ideology (Rabinowitz and Macdonald 1989), and these citizens (of which there are fewer) tend to be more interested and passionate about politics (Adams and Ezrow 2009). Furthermore, these voters have been found to be more stable in their vote intention at the national level (Dassonneville 2012), and they report voting at higher rates than moderate voters.

\footnotetext{
${ }^{6}$ Adams and Merrill's (2009) theoretical study on policy-seeking parties' strategies in multiparty systems concludes that parties are motivated to adjust their policy strategies in response to their beliefs about the median voter position, rather than in response to the diversity of voter ideologies in the electorate.

${ }^{7}$ Informational considerations suggest that mainstream parties will respond to the mean voter position. Since these parties occupy the "crowded center," mainstream parties are unable to differentiate their supporters from other mainstream party supporters. In this environment, they might receive clear policy signals from the electorate as a whole (e.g., through polling), rather than from other subconstituencies like party supporters (Ezrow et al. 2011; cf. Ibenskas and Polk 2019).
} 
The arguments summarized earlier are consistent with the findings of Rodon (2017), who reports stark empirical differences in voter turnout between moderates and other voters. In particular, he attributes the difference to partisanship levels, which are much weaker in the center than to the left or right. Rodon $(2017,150)$ writes the following on partisanship levels for the center, left, and right:

the erosion of party attachments has affected all voters, but this has been unequally distributed across ideological positions. Data collected in this article shows that, on average, the percentage of non-partisan identifiers are higher on the center (48.4 per cent) than on the left (31.3 per cent) or the right (33.2 per cent).

He also reports that low partisanship levels in the middle have the predictable consequence that turnout is lower for moderate citizens. ${ }^{8}$

Although the aforementioned studies are insightful and lend preliminary support to the claim that changes in centrist citizens' turnout rates drive overall changes in turnout, to the best of our knowledge, no study has directly tested whether this actually occurs. Since our argument about party responsiveness to public opinion hinges on this assumption, we report findings in the empirical section that support the finding that changes in rates of turnout are predominantly driven by changes in centrist citizens' turnout decisions.

The theoretical expectation that political parties will be more responsive to public opinion after elections that exhibited a decrease in voter turnout may also vary across types of political party. ${ }^{9}$ For example, some parties may even further prioritize vote or office seeking, such as "dominant" parties, that is, parties that have previously governed, when compared to the "challenger" parties that have not (De Vries and Hobolt 2020). In a similar vein, Klüver and Spoon (2016) and Meguid (2005; Meguid 2008) analyze how mainstream and niche parties represent voters differently (see also Bischof and Wagner 2019). Bawn and Somer-Topcu (2012) report different election strategies for governing and opposition parties. Relatedly, vote-losing and vote-gaining parties have different incentives to change their policy positions (Somer-Topcu 2009). It is possible that other party distinctions matter, such as whether they are centrist or extreme, or large or small. The empirical section reports analyses which suggest that the theory applies to most of these parties and that significant differences only occur in few instances (for challenger and extreme parties). The theory thus has implications for which party types are "center-oriented" and hence more responsive to previous changes in turnout.

To summarize, the preceding discussion of party-type effects notwithstanding, political parties will seek to mobilize moderate voters after elections that are characterized by relatively low voter turnout by appealing to them in policy terms.

The preceding discussion motivates the following declining turnout hypothesis:

HypothesIs 1: Decreases in turnout increase party responsiveness to the median voter position in the following election.

\footnotetext{
${ }^{8}$ Research on second-order elections, such as those to the European Parliament, is insightful in this regard, as these elections are characterized by an unusually low turnout compared with national elections. Franklin (2007) shows that left-right extremism has a positive effect on participation in elections to the European Parliament, suggesting that centrist voters, in particular, abstained in these low-turnout elections. A recent study by Remer-Bollow, Bernhagen, and Rose (2019) addresses to what extent the results of the European Parliament elections would have changed if turnout had risen to the level observed in first-order national elections. They note that ideologically left-wing and moderate parties would have performed better under the condition of a higher turnout. Therefore, it is parties that rely on the vote of centrist voters that would have benefited from increased voter turnout.

${ }^{9} \mathrm{We}$ thank two of the journal's reviewers for encouraging us to explore party-type effects in our analyses.
} 
Exploring this hypothesis enhances our understanding of party competition, and if it is supported, it suggests that an important underemphasized effect of decreased turnout is increased party responsiveness to public opinion in the following election.

\section{Data and Measurement}

To test whether changes in turnout influence party responsiveness, we develop longitudinal, cross-national measures of voter turnout, the median (or mean) voter position, ${ }^{10}$ and parties' policy positions. Our cases include West European democracies for which Eurobarometer mean voter data are available. Countries and years include Austria (1999-2017), Denmark (1977-2015), Finland (2003-15), France (1981-2017), Germany (1980-2017), Great Britain (1979-2017), Greece (1985-2015), Ireland (1981-2016), Italy (1983-2018), the Netherlands (1981-2017), Portugal (1991-2015), Spain (1989-2016), and Sweden (2002-18). ${ }^{11}$

\section{The Dependent Variable: Parties' Left-Right Policy Positions}

Our primary measure of party shifts is from statements from party platforms provided by the Comparative Manifesto Project/Manifesto Project Database (CMP/MARPOR) researchers (Klingemann et al. 2006; Volkens et al. 2018). Party positions (and voter preferences, described later) are measured in terms of "left" and "right." To capture important temporal changes in party position, we employ a panel of elections from thirteen countries ranging from 1977 to 2018. Comprised of the election manifestos from political parties in a wide range of democracies, these data provide cross-national estimates of party policies available for an extended time period. Furthermore, since the content of party programs is often the result of intense intraparty debate, the MARPOR estimates should be reliable and accurate statements about parties' positions at the time of elections. Research has found these measures to be generally consistent with those from other party-positioning studies, such as those based upon expert placements, citizen perceptions of parties' positions, and parliamentary voting analyses (Laver, Benoit, and Garry 2003; Marks 2007; McDonald and Mendes 2001; see also Adams et al. 2019). We measure left-right positions using the logit-transformed scales advocated by Lowe et al. (2011). ${ }^{12}$ The measure has an empirical maximum value of 4.6 (extreme right) and a minimum of -4.5 (extreme left). The dependent variable, $\Delta$ Party Position $(t)$, is then measured as the change in party position from election $t-1$ to $t$. Table A3 in the Online Supporting Information reports all of the parties that are included in the analysis.

\section{Independent Variables: Changes in Voter Turnout, the Mean Voter Position, and Their Interaction}

To test the declining turnout hypothesis, it is necessary to measure voter turnout. Most comparative studies of turnout emphasize the importance of cross-national comparability of the measure. Given the longitudinal nature of this study, it is important that our measure of turnout is consistent over time within each country. The longitudinal measure of voter turnout for our sample is from a dataset provided by the WZB Berlin Social Science Center. ${ }^{13}$

\footnotetext{
${ }^{10}$ The mean of respondents' self-placements is a reasonable approximation of the median because the distributions of respondents' self-placements are generally unimodal and symmetric (Adams and Somer-Topcu 2009b, 682). Ward et al. $(2011,524)$ report a correlation of 0.969 between estimates of the mean and median. The analyses of Powell (2021) further corroborate that when the distribution of citizen self-placements is characterized as normal, there are only slight differences between the use of the mean and the interpolated median.

${ }^{11}$ Belgium and Luxembourg are not included because these are compulsory voting countries. When these countries are included in the empirical analyses, however, the substantive conclusions do not change. Malta is omitted due to insufficient median voter data.

${ }^{12}$ Our results do not change if we use the additive measure proposed by Laver and Budge (1992), which ranges from -100 to +100 .

${ }^{13}$ This dataset includes turnout estimates that have been officially reported by the countries' national election commissions.
} 


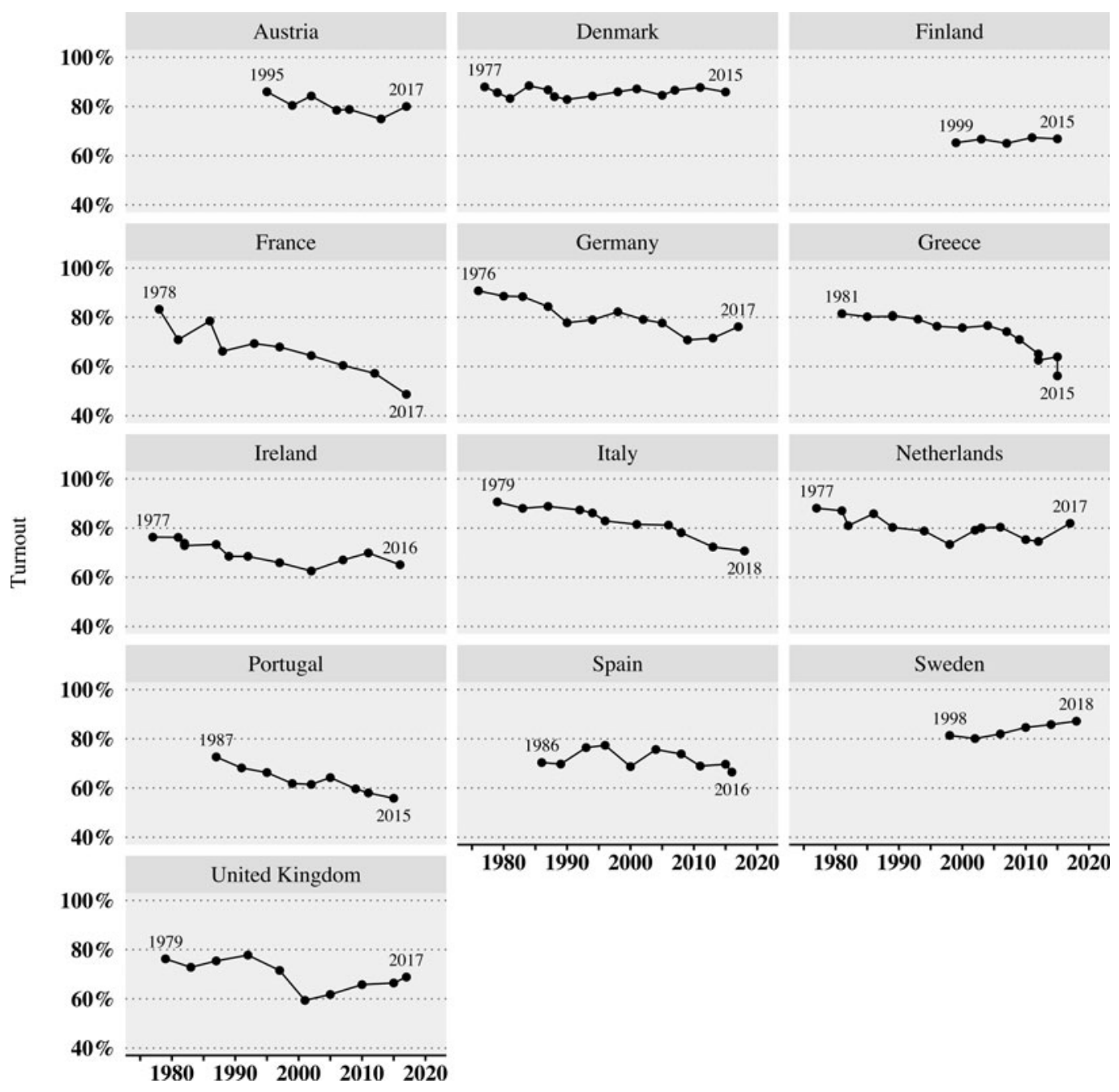

Fig. 1. Voter turnout, 1977-2018.

Notes: The turnout estimates are based on the numbers of eligible voters. The time periods correspond to the coverage of the Eurobarometer surveys (see later).

Estimates of the turnout variable, stratified by country, are presented in Figure 1. The dots represent turnout levels for each election that is included in the empirical analyses, and there are several important patterns to identify. Few countries have constant turnout rates. In France, Portugal, and Italy, participation rates have declined consistently since the 1990s. Other countries, such as Denmark, the Netherlands, or Spain, show fluctuating trends, where turnout decreases and increases alternate. Lastly, in some countries, downward trends have been met with an upward movement, particularly in the most recent elections under study (for example, Austria, Germany, the UK, and Sweden). Overall, there is no common trend that applies to every European country. ${ }^{14}$

\footnotetext{
${ }^{14}$ There are limitations of scope based on the coverage of the Eurobarometer surveys. In particular, the shortened time series of Austria, Spain, Finland, Greece, Portugal, and Sweden is due to these countries entering the dataset as they became members of the European Union.
} 


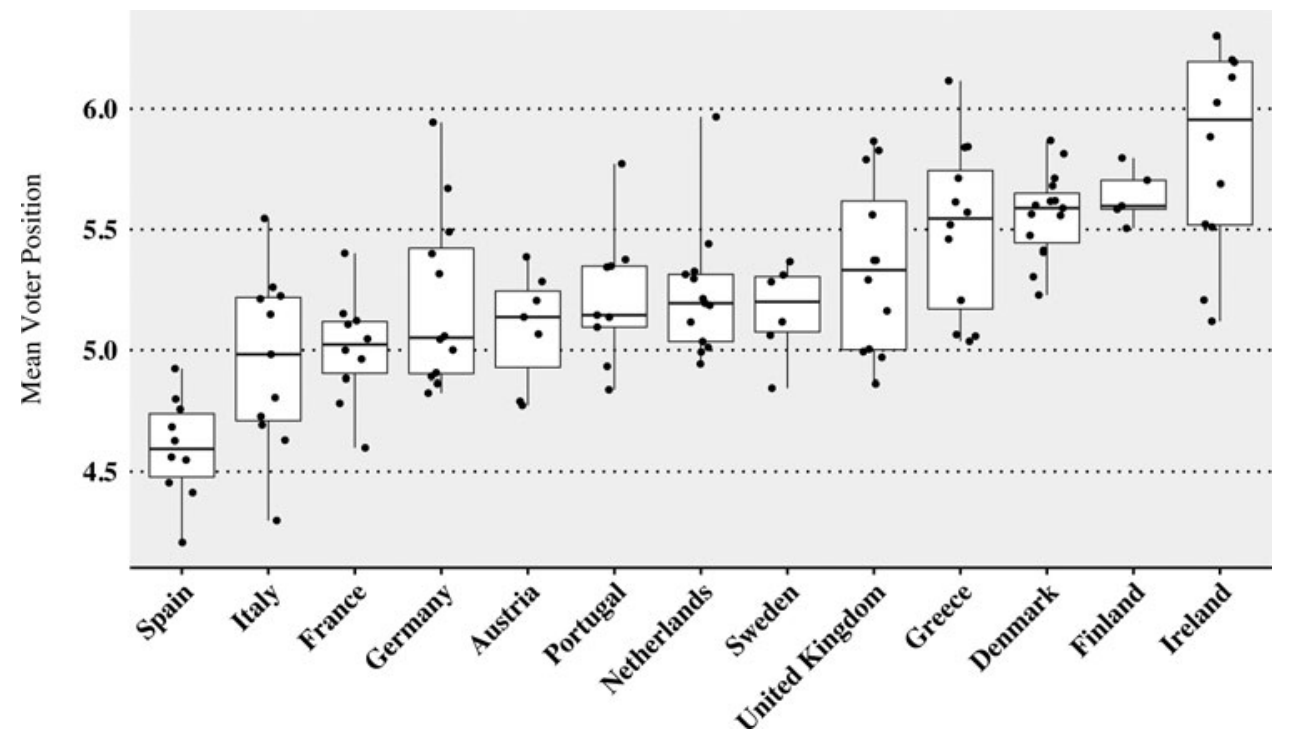

Fig. 2. Mean voter positions, 1975-2018.

Notes: Mean voter position estimates are based on Eurobarometer surveys, which ask respondents to place themselves on a left-right scale from 1 (left) to 10 (right). The boxplots report mean voter positions for each country election included in the study. The boxes show the interquartile ranges of the mean voter positions, with the middle line in each box showing median values. The ends of the whiskers are minimum and maximum values.

Data on mean voter preferences come from the Eurobarometer public opinion surveys that ask respondents to place themselves on a left-right scale from 1 (left) to 10 (right). We focus on voters' (and political parties') left-right positions instead of more detailed conflict dimensions for two reasons. First, comparative survey data for citizens' positions on subdimensions of political conflict (such as the economy or cultural issues) are scarce. Hence, only left-right positions are available for a broad set of countries over extended time periods. Secondly, and more importantly, recent research suggests that left-right positions represent a crucial orientation for voters. As a consequence, left-right congruence between voters and parties is the stronger predictor of vote choice if compared with congruences on political subdimensions (Lichteblau, Giebler, and Wagner 2020; see also Lachat 2018).

As the Eurobarometer does not survey at the exact time of national elections, but rather every six months, we consider only those surveys that were conducted at maximum of one year before the election in question. ${ }^{15}$ Figure 2 gives an overview of the distribution of the mean voter position for all countries under observation. Some countries have seen considerable variation in mean voter positions over time. For instance, the position of the mean voter in Ireland has moved from 6.2 in 1981 to 5.12 in 2016. Similar levels of variation are observable in other countries, such as Germany, Italy, or the UK. Other countries, like Finland, exhibit less variation over time.

\section{Testing Centrist Turnout as a Driver of Overall Turnout}

Before we evaluate the declining turnout hypothesis, we first test the crucial assumption that changes in a country's turnout are affected by changes in turnout among moderate voters. We test for this relationship by making use of election studies provided by the Comparative Study

\footnotetext{
${ }^{15}$ As a consequence, we exclude from our analysis all snap elections that took place less than six months after the previous election.
} 
Table 1. Citizen ideology, turnout, and changes in turnout (individual-level analyses)

\begin{tabular}{lcccc}
\hline & \multicolumn{4}{c}{ DV: Turnout (individual level) } \\
\cline { 2 - 5 } & $(1)$ & $(2)$ & $(3)$ & $(4)$ \\
\hline Left-right extremism (0-6) & $0.090^{\star \star \star}(0.025)$ & $0.102^{\star \star \star}(0.021)$ & $0.073^{\star \star \star}(0.023)$ & $0.088^{\star \star \star}(0.020)$ \\
$\Delta$ Turnout (election level) & & & $0.071^{\star \star \star}(0.026)$ & $0.061^{\star \star}(0.025)$ \\
Left-right extremism * $\Delta$ turnout & & & $-0.012^{\star \star}(0.005)$ & $-0.010^{\star \star}(0.004)$ \\
Controls & No & Yes & No & Yes \\
Random effects (country and survey) & Yes & Yes & Yes & 13 \\
$N$ countries & 13 & 13 & 42 & 42 \\
$N$ country-years & 42 & 42 & $0.248(0.174)$ & $0.137(0.104)$ \\
Var (countries) & $0.268(0.208)$ & $0.140(0.124)$ & $0.230^{\star \star \star}(0.062)$ & $0.265^{\star \star \star}(0.078)$ \\
Var (country-years) & $0.271^{\star \star \star}(0.090)$ & $0.295^{\star \star \star}(0.093)$ & 48442 & 48442 \\
$N$ & 48442 & 48442 & -16092.9 & -15092.1 \\
Log likelihood & -16103.1 & -15099.0 & \\
\hline
\end{tabular}

Notes: Sample and demographic weights used. Left-right extremism $=$ distance to mean voter position. ${ }^{\star \star \star} p<0.01 ;{ }^{\star \star} p<0.05 ;{ }^{\star} p<0.1$. Sources: CSES (2018) and CSES (2020).

of Electoral Systems (CSES), which comprises postelection surveys for the majority of West European countries since 1996 (CSES 2018; CSES 2020). Relying on a question asking survey respondents whether they turned out to vote in the most recent general election, we estimate the parameters of multilevel logit model specifications for the 39 elections in the 13 countries that are covered in the analyses of party responsiveness in the following. We estimate random effects for each country and each survey (Schmidt-Catran and Fairbrother 2016), and we use CSES design and sample weights. We estimate a respondent's left-right extremism score by calculating the distance between their left-right position and the mean voter position. This measure takes the value of 0 if the respondent's left-right position is identical to the mean voter position. The higher the value, the greater is the distance to the mean voter position, and the maximum value of the resulting scale is 6 . The results are similar if we use a binary indicator for centrist (distance 0-1) and noncentrist (distance 2-6) respondents, and these are reported in the Online Supporting Information (Table A2 and Figure A1). We further add a variable at the election level that denotes the change in turnout between the election in question and the previous election. Interacting the variables allows us to evaluate centrist individual turnout probabilities in contexts of declining turnout and then to compare it to estimates for more extreme citizens.

Table 1 reports the corresponding regression results. Models 1 and 2 evaluate whether leftright extremism influences a citizen's probability of voting independent of overall turnout. Model 2 includes a series of additional individual-level covariates that are likely to affect citizens' voting behavior. ${ }^{16}$ These controls include sociodemographic characteristics (age, gender, education, household income, union membership, and employment status) and attitudinal variables (external political efficacy and satisfaction with the working of democracy).

The positive coefficients on left-right extremism confirm that the probability of voting increases for more extreme citizens, which is consistent with previous research (Rodon 2017). Next, Models 3 and 4 report the left-right extremism coefficients that are conditional on changes in turnout. The interaction effect is negative, which suggests not only that centrist voters abstain more often, but also that the gap between the abstention of centrist and extreme voters widens in elections with declining turnout. If declining turnout were not driven by centrist abstention, the estimate on the interaction variable would be insignificant and the probability of voting would decline uniformly for all voters.

\footnotetext{
${ }^{16}$ For the full set of regression results, see Table A1 in the Online Appendix. The estimated effects of the control variables are in the expected direction and statistically significant (with the exception of gender).
} 


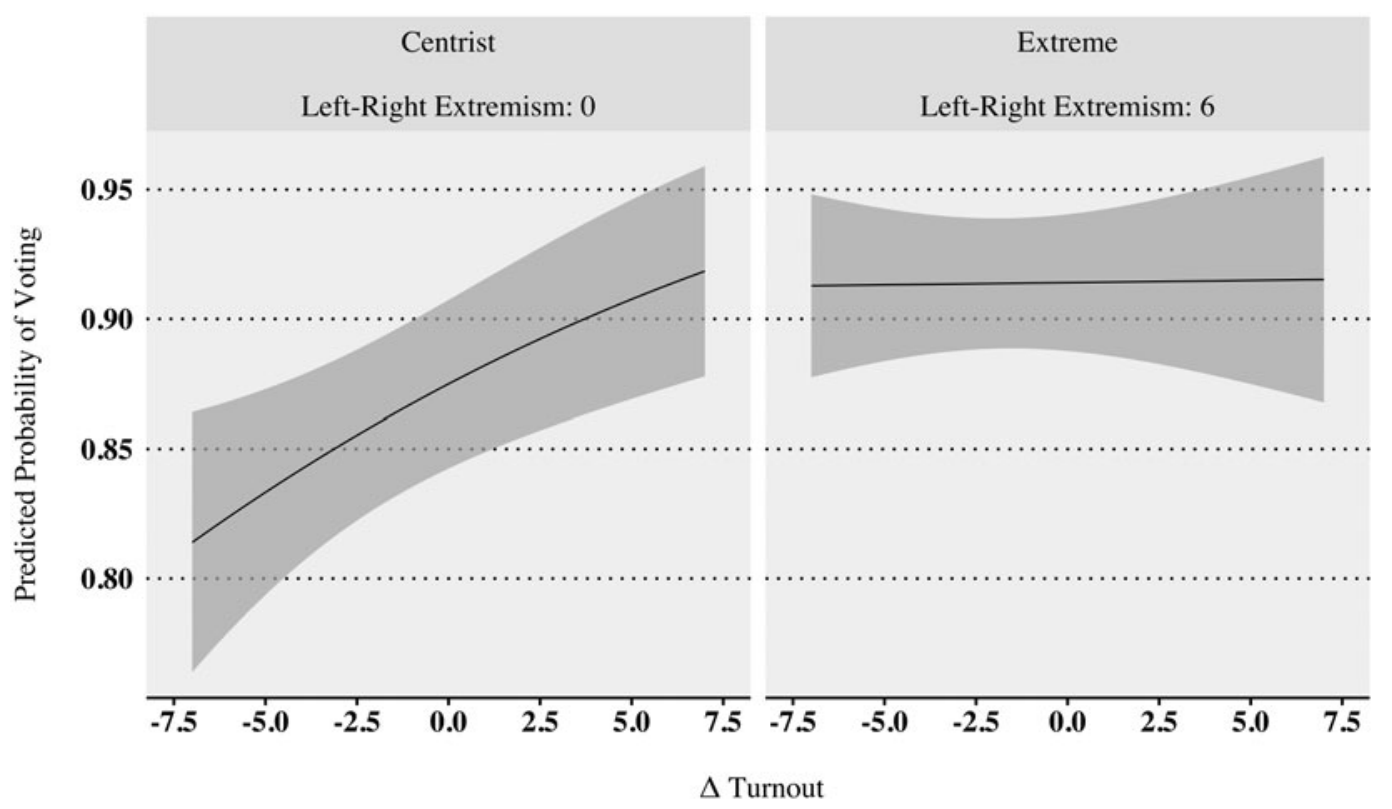

Fig. 3. Predicted probabilities of voting based on individual-level analyses.

Note: Confidence bands show 95 per cent confidence intervals. Estimates are based on Model 3 in Table 1.

Figure 3 clearly depicts this finding using predicted probabilities comparing centrist and extreme citizens. In elections with increasing turnout, the probability of voting is nearly identical for all voters independent of their distance to the mean voter position. If turnout decreases, however, the likelihood of voting only decreases for centrist citizens. Alternatively, turnout change has no discernible effect on voting for extreme citizens. As a consequence, the models indicate that declining turnout is driven to a substantial extent by centrist citizens deciding to abstain. Conversely, increasing turnout is marked by centrist citizens deciding to turn out. We note that the effect sizes should be interpreted with caution, as survey respondents overstate their turnout likelihood in pre- and postelection surveys. Nevertheless, the results indicate that the effect for centrist citizens is substantively significant because the gap in the probability of voting between centrist and extreme respondents varies between 5 and 10 percentage points, depending on the size of the negative turnout change. We thus find support for the assumption that changes in centrist turnout drive overall turnout changes, which is part of the central argument that political parties have a strong incentive to respond to moderate (disaffected) voters in times after declining turnout. On this basis, we proceed.

\section{Testing the Declining Turnout Hypothesis}

It should be recalled that the declining voter turnout hypothesis predicts that parties will respond to changes in the mean voter position after an election that has experienced a decrease in voter turnout. We estimate parameters of "cross-national" ordinary least squares (OLS) regression models to evaluate whether this relationship between responsiveness and turnout is present in our data. This "cross-national" specification is:

$$
\begin{gathered}
\Delta \text { Party Position }(t)=\beta_{0}+\beta_{1}[\Delta \text { Mean Voter }(t)]+\beta_{2}[\Delta \text { Turnout }(t-1)] \\
+\beta_{3}[\Delta \text { Mean Voter }(t)] \times[\Delta \text { Turnout }(t-1)]+\beta_{4} \gamma+\alpha+\varepsilon
\end{gathered}
$$


where $\Delta$ Party Position $(\mathrm{t})$ is defined as the difference between a party's left-right position at election $t$ and its position at the previous election $(t-1) . \Delta$ Mean Voter $(\mathrm{t})$ denotes the difference between the position of the mean voter in the current election $t$ and the mean voter in the previous election $(t-1)$. The lagged $\Delta$ Turnout $(t-1)$ variable is defined as the difference between turnout in the previous election $(t-1)$ and turnout two elections ago $(t-2)$. Moreover, we added country fixed effects $(\alpha)$ to control for time-constant factors (such as electoral system characteristics). Finally, $\gamma$ denotes a vector of time-varying covariates and $\varepsilon$ is the error term.

We add a number of covariates that potentially influence changes in parties' left-right positions. First, the change in a party's vote share may have an influence. In particular, previous election results might constitute different incentives for parties to respond to the mean voter position. For example, the literature on decision rules suggests that vote-winning parties might be inclined to shift in the same direction as in the previous election and vote-losing parties might strategically decide to switch to the opposite direction (Adams et al. 2004; Budge 1994; Somer-Topcu 2009). We thus control for parties' vote changes at $t-1$.

Secondly, parties in government-constrained by the responsibility of policy and decision making - might be restricted in their flexibility to respond to public opinion in order to maintain their programmatic credibility in the face of previous government decisions. Accordingly, we include parties' governing status (that is, governing or opposition) in the model specification. Thirdly, macroeconomic factors possibly restrain parties' ability to maneuver, as parties potentially refrain from proposing positions that are considered unrealistic under economic globalization (Hellwig 2014). We add a measure of the difference in globalization from the current election and the previous election, provided by the KOF Globalization Index (Sturm, Haelg, and Gygli 2018). ${ }^{17}$ Lastly, economic performance could influence party responsiveness. It has been shown that if the economy performs well, parties tend to promote more rightist economic policies if compared with periods when the economy slows down. As a result, we control for the logtransformed change in gross domestic product (GDP) per capita (World Bank 2018) between $t-1$ and $t$.

In total, we estimate a first-difference model that focuses on the impact of changes in our independent variables on the changes in parties' left-right positions. Focusing on changes makes sense theoretically when investigating party responsiveness, and using a first-difference model comes with the advantage of addressing several common problems related to working with (quasi-)panel data. In particular, it addresses the stationarity of the time series and party- and country-specific heterogeneity. Still, serial correlation remains a possibility. Accordingly, we add a lagged dependent variable to the regression equation (Beck and Katz 1995). ${ }^{18}$ Moreover, the error terms might be correlated within units (parties) or time (elections), which could yield unreliable standard errors. We cluster the standard errors based on both types-parties and elections-to account for this potential problem. In total, the analysis encompasses 117 elections.

\section{Results}

The parameter estimates for the cross-national specifications are presented in Models $1 \mathrm{a}$ and $1 \mathrm{~b}$ of Table 2. Model 1a presents the regression results without an interaction term to evaluate whether parties generally tend to respond to public opinion shifts. We retest this hypothesis because previous studies have mostly tested for this relationship with much shorter time series (until 2002). As can be seen, the effect of the $\Delta$ Mean Voter ( $\mathrm{t}$ ) variable is positive and statistically significant. This indicates that political parties do indeed tend to respond to shifts in the mean voter position. This speaks well to previous findings showing that there is a close correspondence

\footnotetext{
${ }^{17}$ Results from previous research also suggest that party responsiveness is enhanced when the country's economy is sufficiently sheltered from the world economy (Ezrow and Hellwig 2014; see also Haupt 2010).

${ }^{18}$ Omitting this variable from the models does not affect the results.
} 
Table 2. Analyses of changes in party position

\begin{tabular}{lcc}
\hline & & DV: Party position $(t)$ \\
\cline { 2 - 3 } & Model 1a & Model $1 \mathrm{~b}$ \\
\hline$\Delta$ Party left-right position $(t-1)$ & $-0.389^{\star \star \star}(0.070)$ & $-0.393^{\star \star \star}(0.068)$ \\
$\Delta$ Mean voter $(t)$ & $0.385^{\star \star \star}(0.143)$ & $0.292^{\star \star}(0.140)$ \\
$\Delta$ Turnout $(t-1)$ & $0.008(0.008)$ & $0.004(0.007)$ \\
$\Delta$ Party vote share $(t-1)$ & $0.077(0.374)$ & $0.040(0.365)$ \\
Party opposition status $(t-1)$ & $0.003(0.050)$ & $0.010(0.050)$ \\
$\Delta$ Globalization $(t)$ & $-0.025(0.025)$ & $-0.021(0.025)$ \\
$\Delta$ GDP per capita (log, $t)$ & $-0.221(0.294)$ & $-0.246(0.275)$ \\
$\Delta$ Mean voter $(t){ }^{*} \Delta$ turnout $(t-1)$ & & $-0.075^{\star \star \star}(0.025)$ \\
Constant & $-0.314(0.215)$ & $-0.286(0.202)$ \\
$N$ & 651 & 651 \\
$R^{2}$ & 0.186 & 0.196 \\
\hline
\end{tabular}

Notes: The dependent variable, $\Delta$ Party Position ( $t$ ), is defined as the difference between a party's left-right position at election $t$ and its position at the previous election at $(t-1)$. The independent variables are defined in the text. Two-way clustered standard errors are reported in parentheses. Country fixed effects not shown. ${ }^{\star \star \star} p<0.01 ;{ }^{\star \star} p<0.05 ;{ }^{*} p<0.1$.

between parties' policy and public opinion shifts (for an overview, see Adams 2012). Model 1b includes an interaction term between turnout change and shifts in the mean voter position and thus tests for the relationship of interest of this article. As expected, the interaction term is negative and statistically significant, supporting the idea that party responsiveness diminishes in times of increasing turnout.

Figure 4 depicts marginal effects to interpret the interaction term, and it supports the finding that political parties tend to be highly responsive in times of declining turnout. However, this effect is conditional on the magnitude of the turnout change. When the value of $\Delta$ Turnout $(t-1)$ drops below 0 (approximately), indicating that turnout decreased in the previous interelection period, the effect of $\Delta$ Mean Voter $(t)$ on $\Delta$ Party Position $(t)$ is positive and statistically significant. These coefficient estimates of party responsiveness to the mean voter position increase as the lagged turnout variable decreases in value. By contrast, the effect of the $\Delta$ Mean Voter $(t)$ variable on the $\Delta$ Party Position $(t)$ variable becomes smaller and insignificant for positive and increasing values on the lagged turnout variable. Hence, the analysis supports the finding that decreasing levels of turnout are met with increasing party responsiveness in the following election. ${ }^{19}$

The conditional effects that are estimated for the $\Delta$ Mean Voter $(t)$ variable are also important because they suggest that the relationship between public opinion shifts and shifts by political parties is one in which the parties respond to public opinion, instead of one in which public opinion responds to parties (or where both parties and the public respond independently to an external factor not accounted for in our specification). ${ }^{20}$ If citizens change their preferences in response to parties' policy shifts, this should affect the $\Delta$ Mean Voter $(t)$ variable similarly across values of the $\Delta$ Turnout $(t-1)$ variable. However, the coefficient on the $\Delta$ Mean Voter $(t)$ variable is only positive and statistically significant under circumstances in which the preceding change in turnout was negative. These estimates are not consistent with a causal process in which public opinion systematically responds to shifts in party ideologies. ${ }^{21}$

\footnotetext{
${ }^{19}$ The marginal effects are similar to those presented if we follow the guidance of Hainmueller, Mummolo, and Xu (2019) by relaxing the linearity assumption of the interaction effect and applying a kernel estimator (see Figure A2 in the Online Supporting Information).

${ }^{20}$ There are persuasive studies which suggest that voters update their policy preferences based on their preferred parties' policy stances (Achen and Bartels 2016; Lenz 2012).

${ }^{21}$ In addition, Table A13 in the Online Supporting Information estimates changes in the mean voter variable based on surveys conducted 4-12 months prior to an election. If parties are uniformly influencing public opinion during campaigns
} 


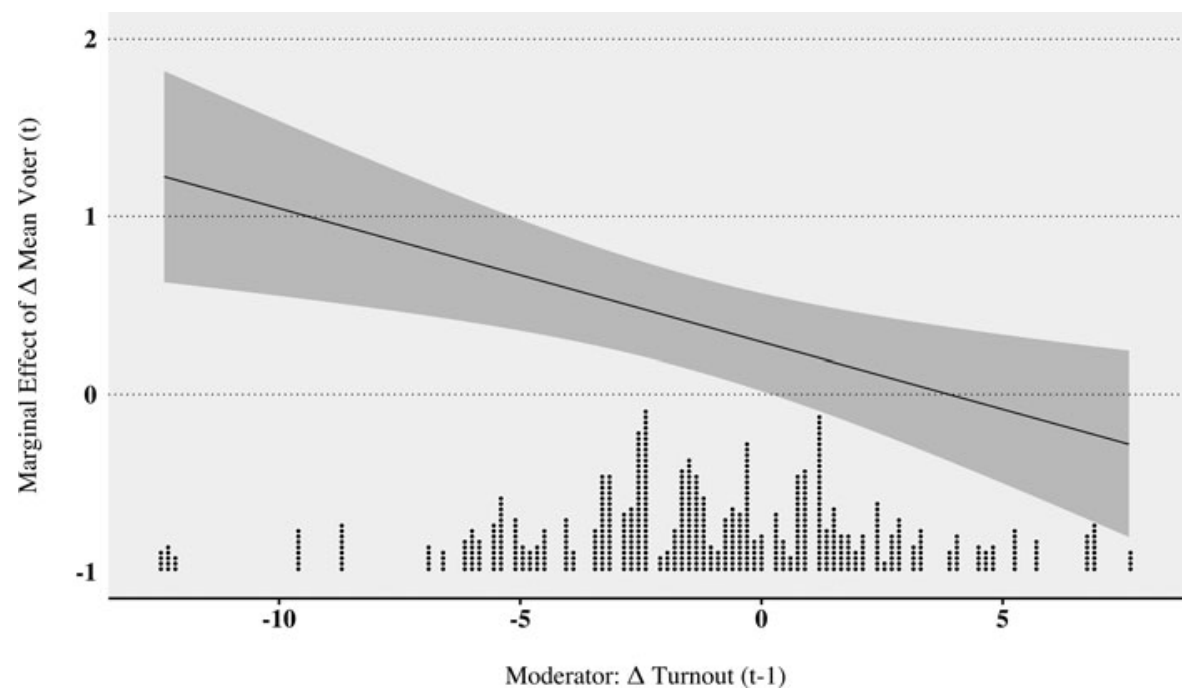

Fig. 4. Effect of mean voter shifts on changes in party position, conditional on the lagged change in voter turnout. Notes: The figure charts the estimated coefficient of $\Delta$ Mean Voter $(\mathrm{t})$ on $\Delta$ Party Position $(\mathrm{t})$ over values of $\Delta$ Turnout $(\mathrm{t}-1)$, as provided by estimates in Model $1 \mathrm{~b}$ of Table 2. The dashed lines report 95 per cent confidence intervals. The dot plot shows the distribution of the turnout values. Omitting cases with values for $\Delta$ Turnout $(\mathrm{t}-1)$ that are greater than +5 per cent or less than -5 per cent does not change the substantive results.

\section{Differential Effects across Party Groups}

Previous research has indicated that not all parties tend to respond to the mean voter to the same extent. Different party types have been assumed to be constrained by their programmatic structure or the composition of their supporters, and, thus, to be less attentive to shifts in the positions of the mean voter. De Vries and Hobolt (2020), for instance, propose that parties that had government experience in the past should be encouraged to prioritize vote- or office-seeking goals, while challenger parties are expected to politicize new issues rather than cater to the center of the left-right dimension (see also De Vries and Hobolt 2012). As a consequence, we expect challenger parties to pay less attention to the mean voter position even when voter turnout has previously decreased. Similarly, smaller parties with less electoral support should be inclined to focus on particular subgroups in the electorate, rather than shifts in the mean voter position. Niche parties, such as radical left, radical right, green, and ethno-territorial parties, have been found to represent voters who care about single policy issues (Adams et al. 2006; Klüver and Spoon 2016; Meguid 2005; Meguid 2008). As a consequence, niche parties might be less incentivized to focus on broader shifts in the electorate. Also, we might expect that the electoral support of extreme parties is not dependent on centrist voters and, thus, that these parties should be less attentive to the mean voter. Bawn and Somer-Topcu (2012) have argued that election strategies differ for governing and opposition parties, and this distinction could potentially matter for our results. Lastly, political parties that have experienced vote losses in a previous election are expected to be less risk averse and, thus, more inclined to change their policy positions (Janda et al. 1995; Somer-Topcu 2009). We provide information on the exact operationalization of these variables in the Online Supporting Information.

We test for the differential responsiveness of all of these party types by adding three-way interactions to the main model presented in Table 2. Table 3 shows the corresponding regression

just before elections, the expectation is that estimates on changes in the mean voter variable would become significantly smaller using this lagged measure. However, the reported estimates are roughly the same. 
Table 3. Empirical analyses of different party types

\begin{tabular}{|c|c|c|c|c|c|c|}
\hline & \multicolumn{6}{|c|}{ DV: $\Delta$ Party left-right position } \\
\hline & $\begin{array}{l}\text { Model 1: challenger (1) } \\
\text { v. dominant (0) }\end{array}$ & $\begin{array}{l}\text { Model 2: niche (1) } \\
\text { v. mainstream (0) }\end{array}$ & $\begin{array}{l}\text { Model 3: opposition (1) } \\
\text { v. government (0) }\end{array}$ & $\begin{array}{l}\text { Model 4: vote winning } \\
\text { (1) v. losing (0) }\end{array}$ & $\begin{array}{l}\text { Model 5: small (1) } \\
\text { v. large }(0)\end{array}$ & $\begin{array}{l}\text { Model 6: extreme (1) } \\
\text { v. nonextreme }(0)\end{array}$ \\
\hline$\Delta$ Mean voter position $(\mathrm{t})$ & $0.268^{\star}(0.161)$ & $0.206(0.150)$ & $0.531^{\star \star}(0.211)$ & $0.343^{\star \star}(0.168)$ & $0.194(0.140)$ & $0.268^{\star}(0.139)$ \\
\hline$\Delta$ Turnout $(\mathrm{t}-1)$ & $0.001(0.010)$ & $-0.001(0.009)$ & $-0.008(0.012)$ & $0.010(0.009)$ & $0.005(0.008)$ & $0.009(0.008)$ \\
\hline Party type & $-0.057(0.068)$ & $-0.037(0.062)$ & $0.014(0.049)$ & $0.046(0.048)$ & $-0.025(0.059)$ & $-0.060(0.061)$ \\
\hline $\begin{array}{l}\Delta \text { Mean voter position }(\mathrm{t}) \\
\Delta \text { turnout }(\mathrm{t}-1)\end{array}$ & $-0.095^{\star \star \star}(0.027)$ & $-0.065^{\star \star}(0.029)$ & $-0.070^{\star \star}(0.034)$ & $-0.070^{\star \star \star}(0.026)$ & $-0.090^{\star \star \star}(0.023)$ & $-0.092^{\star \star \star}(0.024)$ \\
\hline $\begin{array}{l}\Delta \text { Mean voter position }(\mathrm{t}) \\
\text { party type }\end{array}$ & $0.113(0.291)$ & $0.214(0.302)$ & $-0.399(0.255)$ & $-0.112(0.196)$ & $0.235(0.269)$ & $0.179(0.283)$ \\
\hline $\begin{array}{l}\Delta \text { Turnout }(\mathrm{t}-1)^{\star} \\
\text { party type }\end{array}$ & $0.007(0.013)$ & $0.009(0.011)$ & $0.019(0.012)$ & $-0.012(0.010)$ & $-0.005(0.012)$ & $-0.013(0.013)$ \\
\hline $\begin{array}{l}\Delta \text { Mean voter position }(\mathrm{t}){ }^{*} \\
\Delta \text { turnout }(\mathrm{t}-1)^{*} \text { party } \\
\text { type }\end{array}$ & $0.071^{\star \star}(0.033)$ & $-0.026(0.034)$ & $-0.007(0.034)$ & $-0.013(0.036)$ & $0.032(0.039)$ & $0.077^{\star \star}(0.039)$ \\
\hline Constant & $-0.282(0.203)$ & $-0.271(0.202)$ & $-0.289(0.200)$ & $-0.307(0.211)$ & $-0.285(0.203)$ & $-0.276(0.203)$ \\
\hline N (N group “0”/N group “1”) & $651(452 / 199)$ & $651(416 / 235)$ & $651(221 / 430)$ & $651(347 / 304)$ & $651(328 / 323)$ & $651(452 / 199)$ \\
\hline$R^{2}$ & 0.199 & 0.199 & 0.202 & 0.199 & 0.198 & 0.201 \\
\hline
\end{tabular}

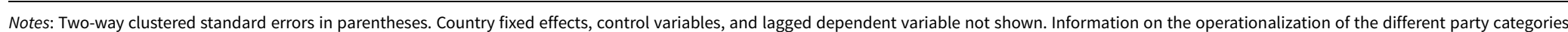
can be found in the Online Supporting Information. ${ }^{\star \star \star} p<0.01$; ${ }^{\star \star} p<0.05 ;{ }^{*} p<0.1$. 
results, and the marginal effects plots can be found in the Online Supporting Information (see Figure A3). It should be noted that the standard errors need to be interpreted with caution due to small group sizes in some specifications. The coefficients of $\Delta$ Mean Voter Position $(t){ }^{*} \Delta$ Turnout $(t-1)$ show the marginal effect for those party groups coded as " 0 " and the three-way interaction- $\Delta$ Mean Voter Position $(t){ }^{*} \Delta$ Turnout $(t-1){ }^{*}$ Party Type-estimates whether the effect is conditioned by party groups coded as " $1 . "$

Overall, we find support for the idea that challenger parties, as defined by De Vries and Hobolt (2020), are less responsive to the mean voter position. The three-way interaction in Model 1 is positive and statistically significant at the 0.05 level, which implies that challenger parties pay less attention to the mean voter position even when voter turnout decreases. A similar effect is visible for extreme parties, which seems plausible because we might expect that most challenger parties are also political parties with more extreme positions on the left-right scale. For the remaining party groups, the three-way interaction estimates are insignificant. The corresponding marginal effects that estimate the conditioning effects of previous turnout on party responsiveness are not significantly different for governing and oppositions parties, large and small parties, or parties who lost or gained electoral support in the previous election. The triple interaction effect for niche parties is also insignificant. One set of arguments suggests that these "ideological" parties have been shown to respond more to their supporters than to the mean voter position (Ezrow et al. 2011). However, recent research suggests that the programmatic "nicheness" of parties is a dynamic rather than a manifest feature of parties. In particular, larger and older niche parties are expected to focus on voter groups beyond their core supporters (see, for example, Bergman and Flatt 2020; De Vries and Hobolt 2020) and could thus be more responsive to shifts in the mean voter position. Our estimates corroborate this latter set of findings.

Table 3 indicates that the marginal effect is only significant for centrist parties after a previous decrease in turnout. The estimated effect of responsiveness to the mean voter for extreme and challenger parties is not statistically significant across the whole range of the change in turnout in the previous election (see Figures A3.1 and A3.6 in the Online Supporting Information). In total, these additional analyses lend considerable support to the declining turnout hypothesis. With few exceptions, such as with challenger and extreme parties, the idea of increasing responsiveness after turnout decline in the previous election applies to several party categories.

\section{Robustness}

We have conducted a number of robustness tests to make sure that our findings are not due to decisions related to modelling strategies or to the operationalization of the variables of interest. We investigated whether the findings are dependent on modelling decisions. Table A4 in the Online Appendix presents a number of alternative specifications. First, we tested whether adding party fixed effects or omitting fixed effects changes the results (Models 1 and 2). Secondly, we omitted the lagged dependent variable to investigate whether potential Nickell bias influences the results (Model 3) and use lagged levels of the dependent variable, as left-right shifts might be restricted by the party's "starting point" on the left-right scale (Model 4). Next, applying clustered standard errors with a reduced number of clusters might unexpectedly deflate the standard errors. For that reason, we ran additional models for which we used only party-clustered (Model 5), only election-clustered (Model 6), and no clustered standard errors (Model 7). The parameter estimates for each of these model specifications continue to support the central conclusion that we report.

Additional robustness analyses are also reported in the Online Supplementary Information. We estimate parameters for: models in which parties' left-right shifts are based on a bipolar measure (Laver and Budge 1992), rather than a logit-transformed scale (see Table A4, Model 8); an error-correction model (see Table A5); low- and high-turnout contexts in Table A6 (see, respectively, Dreyer and Bauer 2019; Hooghe, Dassonneville, and Oser 2019), models that 
account for trending (see Table A7); jackknife analyses (see Figure A4); models that estimate the mean voter position based on different "windows" before the election in which public opinion was collected (see Table A8); omitting observations for which materials other than manifestos (for example, party bloc programs) were used to estimate party positions (see Table A9); models that address very small changes in public opinion (see Table A10); models that control for several additional independent variables that potentially influence turnout and party responsiveness simultaneously, including globalization, competitiveness, and polarization (see Table A11); and, following Ferland (2020; see also Adams et al. 2004), models that control for the direction of public opinion shifts in relation to each political party (see Table A12 and Figure A5).

\section{Conclusion}

One reason why voter turnout is considered a main indicator of a healthy democracy is that it is thought to enhance elite responsiveness to public opinion (see, for example, Powell 1986). The contribution of this study is to show that decreases in turnout are important because they motivate greater party responsiveness in future elections. If abstention signals dissatisfaction, it is potentially a positive finding for the democracies in our sample that parties are more responsive to the mean voter position after an election with relatively low turnout. On the other hand, when citizens do not turn out and elites do not respond, this would then signal concern for democracy. We find that parties in established democracies do respond to decreasing turnout by increasing their responsiveness to the median voter in the following election.

The finding that declines in aggregate levels of turnout are associated with increases in levels of party responsiveness within these democracies raises several interesting questions for future research. Our sample of democracies is limited, in that we examine only established democracies. Newer democracies may not exhibit similar patterns. There is also an issue that party responsiveness may influence turnout. Although the analyses are based on previous changes in voter turnout, a thorough exploration of how responsiveness can affect voter turnout is an important next step. Future studies should also analyze how changes in turnout condition government policy responsiveness to the mean voter position (see Powell 2000; Soroka and Wlezien 2010) and whether relatively low turnout motivates future governments to respond to the median voter position. $^{22}$

Furthermore, there are a number of additional conditional effects worth exploring. If parties are sensitive to the median voter after an election with decreasing turnout, an extension of the Downsian model might suggest that our findings would increase in disproportional electoral systems or party systems that feature only two parties, which have been argued to be more sensitive to the median voter position (Cox 1990; see also Dow 2001; Dow 2011). Parties' organizational structures may also matter for party responsiveness in contexts of decreasing turnout. The research that follows should examine whether internally divided democratic parties (Lehrer 2012; Schumacher, De Vries, and Vis 2013) exhibit less responsiveness to the median voter after decreasing turnout because party leadership is more constrained by party membership.

Our findings have important implications for literature concerned with unequal participation. While declining voter turnout is associated with the increasingly unequal participation of lower and upper socio-economic groups (Schäfer and Schwander 2019; Solt 2008), our analysis suggests that decreasing turnout is driven by voters who position themselves at the center of the voter distribution. It remains an important task for future research to link these two different findings. A related extension will evaluate whether it is an effective electoral strategy for political parties to respond to the median voter position after a decline in turnout.

\footnotetext{
${ }^{22}$ Hooghe, Dassonneville, and Oser (2019) report that voter turnout enhances government policy responsiveness to the median voter. Follow-up studies should thus focus on temporal effects and how government policy responds to decreases in turnout over time.
} 
This study examines the intuition that enhanced turnout benefits democracy because it motivates elite responsiveness. Our longitudinal findings suggest that this is the case but just not quite how analysts of democracy might assume. We find that decreasing turnout in an election enhances party responsiveness to the median voter in the next election. Future research will examine additional conditions for how turnout influences elite responsiveness to public opinion. We hope that it will not overlook the possibility that a decrease in turnout will enhance responsiveness under some conditions.

Supplementary Material. Online appendices are available at: https://doi.org/10.1017/S0007123421000673

Data Availability Statement. Replication data are available at the British Journal of Political Science's Dataverse, available at: https://doi.org/10.7910/DVN/PQ63DN

Acknowledgments. The authors thank the editors, four anonymous reviewers, James Adams, Christian Breunig, Jane Green, Thomas Meyer, and Aiko Wagner for helpful comments on previous versions of the article.

Financial Support. None.

Competing Interests. There are no competing interests involved with the completion of this project.

\section{References}

Achen CH and Bartels LM (2016) Democracy for Realists: Why Elections Do Not Produce Responsive Government. Princeton, NJ: Princeton University Press.

Adams J (2012) Causes and electoral consequences of party policy shifts in multiparty elections: theoretical results and empirical evidence. Annual Review of Political Science 15(1), 401-419.

Adams J and Ezrow L (2009) Who do European parties represent? How Western European parties represent the policy preferences of opinion leaders. Journal of Politics 71(1), 206-223.

Adams J and Merrill S III (2009) Policy-seeking parties in a parliamentary democracy with proportional representation: a valence-uncertainty model. British Journal of Political Science 39(3), 539-558.

Adams J and Somer-Topcu Z (2009a) Do parties adjust their policies in response to rival parties' policy shifts? Spatial theory and the dynamics of party competition in twenty-five postwar democracies. British Journal of Political Science 39(4), 825-846.

Adams J and Somer-Topcu Z (2009b) Moderate now, win votes later: the electoral consequences of parties' policy shifts in 25 postwar democracies. Journal of Politics 71(2), 678-692.

Adams J, Dow J and Merrill S III (2006) The political consequences of abstention from alienation and abstention from indifference: applications to presidential elections. Political Behavior 28, 65-86.

Adams J et al. (2004) Understanding change and stability in party ideologies: do parties respond to public opinion or to past election results? British Journal of Political Science 34(4), 589-610.

Adams J et al. (2006) Are niche parties fundamentally different from mainstream parties? The causes and electoral consequences of Western European parties' policy shifts, 1976-98. American Journal of Political Science 50(3), 513-529.

Adams J et al. (2019) A problem with empirical studies of party policy shifts: alternative measures of party shifts are uncorrelated. European Journal of Political Research 58(4), 1234-1244.

Anderson CJ and Guillory CA (1997) Political institutions and satisfaction with democracy: a cross-national analysis of consensus and majoritarian systems. American Political Science Review 91(1), 66-81.

Bawn K and Somer-Topcu Z (2012) Government versus opposition at the polls: how governing status affects the impact of policy positions. American Journal of Political Science 56(2), 433-446.

Beck N and Katz JN (1995) What to do (and not to do) with time-series cross-section data. American Political Science Review 89(3), 634-647.

Bergman ME and Flatt $\mathbf{H}$ (2020) Issue diversification. Which niche parties can succeed electorally by broadening their agenda? Political Studies 68(3), 710-730.

Bischof D and Wagner M (2019) Do voters polarize when radical parties enter parliament? American Journal of Political Science 63(4), 888-904.

Blais A (2000) To Vote or Not to Vote? The Merits and Limits of Rational Choice Theory. Pittsburgh, PA: University of Pittsburgh Press.

Budge I (1994) A new spatial theory of party competition: uncertainty, ideology and policy equilibria viewed comparatively and temporally. British Journal of Political Science 24(4), 443-467.

Budge I, Ezrow L and McDonald M (2010) Ideology, party factionalism and policy change: an integrated dynamic theory. British Journal of Political Science 40, 781-804.

Cox GW (1990) Centripetal and centrifugal incentives in electoral systems. American Journal of Political Science 34(4), 903-935. 
CSES (Comparative Study of Electoral Systems) (2018) CSES Integrated Module Dataset (IMD). Available from https://cses.org

CSES (2020) CSES Module 5 Advanced Release 2. Available from https://cses.org

Dalton RJ (2006) Citizen Politics: Public Opinion and Political Parties in Advanced Industrial Democracies. New York, NY: Chatham House.

Dassonneville R (2012) Electoral volatility, political sophistication, trust and efficacy: a study on changes in voter preferences during the Belgian regional elections of 2009. Acta Politica 47(1), 18-41.

Dassonneville R (2018) Electoral volatility and parties' ideological responsiveness. European Journal of Political Research 57(4), 808-828.

De Vries CE and Hobolt SB (2012) When dimensions collide: the electoral success of issue entrepreneurs. European Union Politics 13(2), 246-268.

De Vries CE and Hobolt SB (2020) Political Entrepreneurs: The Rise of Challenger Parties in Europe. Princeton, NJ: Princeton University Press.

Dow JK (2001) A comparative spatial analysis of majoritarian and proportional elections. Electoral Studies 20(1), $109-125$.

Dow JK (2011) Party-system extremism in majoritarian and proportional electoral systems. British Journal of Political Science 41(2), 341-361.

Downs A (1957) An Economic Theory of Democracy. Boston, MA: Addison-Wesley.

Dreyer P and Bauer J (2019) Does voter polarization induce party extremism? The moderating role of abstention. West European Politics 42(4), 824-847.

Erikson RS, MacKuen MB and Stimson JA (2002) The Macro Polity. Cambridge: Cambridge University Press.

Ezrow L and Hellwig T (2014) Responding to voters or responding to markets? Political parties and public opinion in an era of globalization. International Studies Quarterly 58(4), 816-827.

Ezrow L and Krause W (2022) Replication Data for: "Voter Turnout Decline and Party Responsiveness," https://doi.org/10. 7910/DVN/PQ63DN, Harvard Dataverse, V1. UNF:6:TZMLFMHkc5zhxpm7OIP2rg = =

Ezrow L and Xezonakis G (2016) Satisfaction with democracy and voter turnout: a temporal perspective. Party Politics 22(1), 3-14.

Ezrow L et al. (2011) Mean voter representation and partisan constituency representation: do parties respond to the mean voter position or to their supporters? Party Politics 17(3), 275-301.

Ferland B (2020) Party responsiveness to public opinion and party supporters: revisiting the mechanisms and motivations. Party Politics 26(4), 366-378.

Franklin M (2004) Voter Turnout and the Dynamics of Electoral Competition in Established Democracies since 1945. Cambridge: Cambridge University Press.

Franklin M (2007) Turning out or turning off? How the European Parliament elections of 2004 shed light on turnout dynamics. In Marsh M, Mikhaylov S and Schmitt H (eds), European Elections after Eastern Enlargement. Mannheim: Connex, pp. 53-69.

Hainmueller J, Mummolo J and Xu Y (2019) How much should we trust estimates from multiplicative interaction models? Simple tools to improve empirical practice. Political Analysis 27(2), 163-192.

Haupt AB (2010) Parties' responses to economic globalization: what is left for the Left and right for the Right? Party Politics 16(1), 5-27.

Hellwig T (2014) Globalization and Mass Politics. New York, NY: Cambridge University Press.

Hobolt SB (2012) Citizen satisfaction with democracy in the European Union. Journal of Common Market Studies 50(1), 88-105.

Hobolt SB and Hoerner JM (2020) The mobilising effect of political choice. European Journal of Political Research 59(2), 229-247.

Homola J (2019) Are parties equally responsive to women and men? British Journal of Political Science 49, 957-975.

Hooghe M, Dassonneville R and Oser J (2019) Public opinion, turnout, and social policy: a comparative analysis of policy congruence in European liberal democracies. Political Studies 67(4), 992-1009.

Huber J and Powell GB (1994) Congruence between citizens and policymakers in two visions of democracy. World Politics 46(3), 291-326.

Ibenskas R and Polk J (2019) Congruence and Party Responsiveness in Western Europe in the 21st Century. Paper presented at the Partisan Divides Workshop at the University of North Carolina at Chapel Hill, USA, May 3-4.

Janda K et al. (1995) Changes in party identity: evidence from party manifestos. Party Politics 1(2), 171-196.

Kirchheimer O (1966) The transformation of Western European party systems. In La Palombara J and Weiner M (eds), Political Parties and Political Development. Princeton, NJ: Princeton University Press, pp. 177-200.

Kitschelt H (1997) European party systems: continuity and change. In Rhodes M, Heywood P and Wright V (eds), Developments in West European Politics. New York, NY: St. Martin's Press, pp. 131-150.

Klingemann HD et al. (2006) Mapping Policy Preferences II: Estimates for Parties, Electors, and Governments in Eastern Europe, European Union, and OECD 1990-2003. Oxford and New York, NY: Oxford University Press.

Klüver H and Spoon JJ (2016) Who responds? Voters, parties, and issue attention. British Journal of Political Science 46(3), 633-654. 
Lachat R (2018) Which way from left to right? On the relation between voters' issue preferences and left-right orientation in West European democracies. International Political Science Review 39(4), 419-435.

Laver M (2005) Policy and the dynamics of political competition. American Political Science Review 99(2), $263-281$.

Laver M and Budge I (1992) Party Policy and Government Coalitions. New York, NY: St. Martin's Press.

Laver M, Benoit K and Garry J (2003) Extracting policy positions from political texts using words as data. American Political Science Review 97(2), 311-331.

Lefkofridi Z, Giger N and Gallego A (2014) Electoral participation in pursuit of policy representation: ideological congruence and voter turnout. Journal of Elections, Public Opinion and Parties 24(3), 291-311.

Lehrer R (2012) Intra-party democracy and party responsiveness. West European Politics 35(6), 1295-1319.

Lenz G (2012) Follow the Leader? How Voters Respond to Politicians' Performance and Policies. Chicago, IL: University of Chicago Press.

Lichteblau J, Giebler H and Wagner A (2020) Do parties perceive their voter potentials correctly? Reconsidering the spatial logic of electoral competition. Electoral Studies 65, 102-126.

Lijphart A (1997) Unequal participation: democracy's unresolved dilemma. American Political Science Review 91(1), 1-14.

Lindvall J, Rueda D and Zhai H (2021) Median Voters, Mainstream Parties, and Electoral Competition. Unpublished manuscript.

Lowe W et al. (2011) Scaling policy preferences from coded political texts. Legislative Studies Quarterly 36(1), $123-155$.

Marks G (2007) Triangulation and the square root law. Electoral Studies 26, 1-10.

McDonald M and Budge I (2005) Elections, Parties, Democracies: Conferring the Median Mandate. Oxford: Oxford University Press.

McDonald M and Mendes S (2001) Checking the party policy estimates: convergent validity. In Budge I et al. (eds), Mapping Policy Preferences: Estimates for Parties, Electors, and Governments 1945-1998. Oxford: Oxford University Press, pp. 127-142.

Meguid BM (2005) Competition between unequals. The role of mainstream party strategy in niche party success. American Political Science Review 99(3), 347-359.

Meguid BM (2008) Party Competition between Unequals. Strategies and Electoral Fortunes in Western Europe. New York, NY: Cambridge University Press.

Müller WC and Strøm K (1999) Policy, Office, or Votes? How Political Parties in Western Europe Make Hard Decisions. Cambridge: Cambridge University Press.

Norris P (2002) Democratic Phoenix: Reinventing Political Activism. Cambridge: Cambridge University Press.

Plane D and Gershtenson J (2004) Candidates' ideological locations, abstention, and turnout in U.S. midterm Senate elections. Political Behavior 26, 69-93.

Powell GB (1986) American voter turnout in comparative perspective. American Political Science Review 80(1), 17-43.

Powell GB (2000) Elections as Instruments of Democracy: Majoritarian and Proportional Visions. New Haven, CT: Yale University Press.

Powell GB (2021) Benchmarking Ideological Representation: Citizen Medians, Interpolated Medians, Means-When Do They Differ? When Does It Matter? Paper prepared for presentation at the annual meeting of the Midwest Political Science Association, Chicago, USA.

Rabinowitz G and Macdonald SE (1989) A directional theory of issue voting. American Political Science Review 83(1), 93-121.

Reher S (2014) The effect of congruence in policy priorities on electoral participation. Electoral Studies 36, $158-172$.

Remer-Bollow U, Bernhagen P and Rose R (2019) Partisan consequences of low turnout at elections to the European Parliament. Electoral Studies 59, 87-98.

Rodon T (2017) When the kingmaker stays home: revisiting the ideological bias on turnout. Party Politics 23(2), 148-159.

Schäfer A and Schwander H (2019) Don't play if you can't win: does economic inequality undermine political equality? European Political Science Review 11(3), 395-413.

Schmidt-Catran AW and Fairbrother M (2016) The random effects in multilevel models: getting them wrong and getting them right. European Sociological Review 32(1), 23-38.

Schumacher G, De Vries CE and Vis B (2013) Why do parties change position? Party organization and environmental incentives. Journal of Politics 75(2), 464-477.

Solt F (2008) Economic inequality and democratic political engagement. American Journal of Political Science 52(1), 48-60.

Somer-Topcu Z (2009) Timely decisions: the effects of past national elections on party policy change. Journal of Politics 71(1), 238-248.

Somer-Topcu Z (2015) Everything to everyone: the electoral consequences of the broad-appeal strategy in Europe. American Journal of Political Science 59(4), 841-854.

Soroka S and Wlezien C (2010) Degrees of Democracy: Politics, Public Opinion, Policy. Cambridge: Cambridge University Press. Spoon JJ (2011) Political Survival of Small Parties in Europe. Ann Arbor, MI: University of Michigan Press.

Spoon JJ and Klüver H (2014) Do parties respond? How electoral context influences party responsiveness. Electoral Studies $35,48-60$. 
Spoon JJ and Klüver H (2015) Voter polarization and party responsiveness: why parties emphasize divided issues, but remain silent on unified issues. European Journal of Political Research 54(2), 343-362.

Stimson JA, Mackuen MB and Erikson RS (1995) Dynamic representation. American Political Science Review 89(3), $543-565$. Sturm JE, Haelg F and Gygli S (2018) The KOF Globalisation Index-revisited. KOF Working Papers 439, 1-50.

Van Kersbergen K (1999) Contemporary Christian democracy and the demise of the politics of mediation. In Kitschelt $\mathrm{H}$ et al. (eds) Continuity and Change in Contemporary Capitalism. Cambridge: Cambridge University Press, pp. 346-370.

Volkens A et al. (2018) Manifesto Project dataset. Manifesto Project. Available from https://doi.org/10.25522/manifesto.mpds. $2018 \mathrm{~b}$

Ward H, Ezrow L and Dorussen H (2011) Globalization, party positions, and the median voter. World Politics 63(3), 509-547.

Williams C and Spoon JJ (2015) Differentiated party response: the effect of Euroskeptic public opinion on party positions. European Union Politics 16(2), 176-193.

Wlezien C (1995) The public as thermostat: dynamics of preferences for spending. American Journal of Political Science 39(4), 981-1000.

Wlezien C (1996) Dynamics of representation: the case of US spending on defence. British Journal of Political Science 26(1), 81-103.

World Bank (2018) GDP per Capita (Current LCU). Available from https://data.worldbank.org/indicator/NY.GDP.PCAP.CN

Cite this article: Ezrow L, Krause W (2023). Voter Turnout Decline and Party Responsiveness. British Journal of Political Science 53, 85-103. https://doi.org/10.1017/S0007123421000673 